九州大学学術情報リポジトリ

Kyushu University Institutional Repository

Effect of Topdressing at Panicle by Pouring Nitrogen Fertilizer Application on Growth, Yield of Rice and Labor Cost of Fertilization in Large-Scale Paddy Feild

PATHIRANA, U. A. Prabath

Yokotanojo Co. Ltd. I Laboratory of Agriculture and Farm Management, Department of Agriculture and Resource Economics, Faculty of Agriculture, Kyushu University

MATSUE, Yuj i

Laboratory of Agriculture and Farm Management, Department of Agriculture and Resource

Economics, Faculty of Agriculture, Kyushu University

NANSEKI, Teruaki

Laboratory of Agriculture and Farm Management, Department of Agriculture and Resource Economics, Faculty of Agriculture, Kyushu University

YOKOTA, Shuichi

Yokotanojo Co. Ltd. I Laboratory of Agriculture and Farm Management, Department of Agriculture and Resource Economics, Faculty of Agriculture, Kyushu University

他

https://doi.org/10.5109/1955672

出版情報：九州大学大学院農学研究院紀要. 63 (2)，pp.487-494，2018-09-01. Faculty of Agriculture, Kyushu University

バージョン :

権利関係 : 


\title{
Effect of Topdressing at Panicle by Pouring Nitrogen Fertilizer Application on Growth, Yield of Rice and Labor Cost of Fertilization in Large-Scale Paddy Feild
}

\author{
U. A. Prabath PATHIRANA ${ }^{1}$, Yuji MATSUE ${ }^{2}$, Teruaki NANSEKI ${ }^{2 *}$, \\ Shuichi YOKOTA ${ }^{1}$ and Yosuke CHOMEI ${ }^{2}$
}

\author{
Laboratory of Agriculture and Farm Management, Department of Agriculture and Resource Economics, \\ Faculty of Agriculture, Kyushu University, Fukuoka 812-8581, Japan \\ (Received May 1, 2018 and accepted May 8, 2018)
}

\begin{abstract}
This study was conducted to investigate the efficiency of pouring nitrogen $(\mathrm{N})$ fertilizer application (PA) method at panicle formation stage and its effects on growth, yield of rice and labor cost of fertilization in large-scale paddy field in Japan. Compared with granular N fertilizer application (GA) method, PA method was characterized by significantly lower yield variation and less labor cost for fertilizer application with in a field. Higher SPAD value and leaf N content were responsible for the higher grain yield under PA method. The yield variation within the same field was significant for GA method and not significant for PA method suggested that the uniformity and accuracy of $\mathrm{N}$ distribution with PA method is higher than GA method. Further, PA method reduced labor cost of about 80\% than GA method for $\mathrm{N}$ fertilizer application at panicle formation stage, suggesting major advantage in PA method for reducing of cost of production. Overall, this quantitative evaluation of two fertilization application methods as $\mathrm{N}$ fertilizer application at panicle formation stage for rice highlights that the PA method has great potential of saving labor cost and reduce yield variation in large-scale paddy field.
\end{abstract}

Key words: "Labor cost" "Large-scale paddy field" "Pouring application method" "Rice" "Yield"

\section{INTRODUCTION}

As the younger population has moved out of agriculture and migrates to cities for urban employment, the aging farming population in rural areas has become more prominent and big issue in Japan. Consequently, the agriculture sector will increase the reliance on the elderly population for labor. The aging of producers in the low capital-intensive agricultural sector could imply lowering of the productivity of labor (Supaporn et al., 2012).

As measures to solve this problem, accumulation of small agricultural lands, making full use of agricultural land by diverse players such as corporate management, large-scale family management, village farming, enterprises, etc. are important (Nanseki et al., 2016). There are many benefits of accumulation of land, including the ability to increase productivity through mechanization, labor productivity through the effective organization and monitoring of production, optimizing fixed capital; to reduce input costs per unit average (seed, fertilizer, etc.); and to increase transport efficiency.

Therefore, one of the urgent tasks of paddy rice production industry is the establishment of the development and introduction of laborsaving and low cost cultivation technology on the premise of large-scale rice cultivation management. Thus we aim to develop a large-scale, labor saving and low cost nitrogen $(\mathrm{N})$ fertilizer application method. It is pouring $\mathrm{N}$ fertilizer

\footnotetext{
Yokotanojo Co. Ltd., Nurutomachi 2047, Ryugasaki, Ibaraki 301-0803, Japan

${ }^{2}$ Faculty of Agriculture, Kyushu University, Hakozaki 6-10-1, Fukuoka 812-8581, Japan

* Corresponding author. (E-mail: nanseki@agr.kyushu-u.ac.jp)
}

application method in which urea fertilizer dissolved in water and distributed with irrigation water from the water inlet of the paddy field. There are prior studies on the evaluation of $\mathrm{N}$ fertilizer application under pouring fertilizer application method and its effects on growth, yield and quality of the rice (Ichikawa et al., 1995 and Saito et al., 1997). However, we have not found the on-farm evaluation reports on the yield and cost reduction of large-scale rice farm under the pouring nitrogen fertilizer application method. Therefore, the present study was undertaken to elucidate the effects of pouring $\mathrm{N}$ fertilizer application method for large-scale farming on growth, yield of rice and labor cost of fertilization.

\section{MATERIALS AND METHODS}

\section{Site descriptions}

On-farm experiment was conducted at the Yokotanojo Co. Ltd. ( $35^{\circ} 54^{\prime} \mathrm{N}, 140^{\circ} 14^{\prime} \mathrm{E}$, and $\left.2.49 \mathrm{~m} \mathrm{ASL}\right)$ in Ryugasaki city, Ibaraki prefecture, Japan during the rice growing season (from late April to October) in 2015. The soil at the experimental site was a low-moor peat soil (hemic histosol) with $6 \%$ organic matter. The temperature dynamics, rainfall distribution and solar radiation data were collected at a meteorological station $200 \mathrm{~m}$ away from the center of experimental site. The average experimental rice field size was about $10,000 \mathrm{~m}^{2}$.

\section{Crop management and fertilizer application}

Three-week-old rice seedlings (cv. Yumehitachi) were transplanted from $11^{\text {th }}$ June to $14^{\text {th }}$ June 2015 . The planting density was 15.5 hills $\mathrm{m}^{-2}$ (hill spacing of $0.3 \mathrm{~m}$ $\times 0.2 \mathrm{~m}$ ) with 4 to 6 seedlings per hill. The field was evenly irrigated to continuously maintain the water level 
at 3 to $5 \mathrm{~cm}$ above the soil. Five grams of $\mathrm{N} \mathrm{m}^{-2}, 5 \mathrm{~g}$ of $\mathrm{P} \mathrm{m}^{-2}$, and $2.5 \mathrm{~g}$ of $\mathrm{K} \mathrm{m}^{-2}$ (poultry manure, $\mathrm{N}: \mathrm{P}: \mathrm{K}=4: 4$ :

2) was applied as basal dressing on $5^{\text {th }}$ June 2015 , and further urea fertilizer was applied as top-dressing at $3 \mathrm{~g}$ of $\mathrm{N} \mathrm{m}^{-2}$ rate on $4^{\text {th }}$ August 2015, 16 to 18 days before heading when the length of young panicle reached approximately $2 \mathrm{~mm}$. This field experiment was composed of six experimental treatments (consisting of two fertilizer application methods combined with three locations in each field) arranged in a randomized block design, and replicated thrice. The two urea fertilizer application methods were: (1) Granular application (GA) method, in which urea fertilizer applied in the form of solid granules by granule spreader (Fig. 1 A). (2) Pouring application (PA) method, in which the fields were drained before fertilization, then $9 \mathrm{~kg}$ of urea dissolved with $27 \mathrm{~L}$ of water in $45 \mathrm{~L}$ plastic container (One container required for $3000 \mathrm{~m}^{2}$ paddy land) and distributed at $3 \mathrm{~mL} / \mathrm{sec}$ rate with irrigation water (Fig. $1 \mathrm{~B}$ ). After fertilizer applied by PA method, the amount of irrigated water (mixed with dissolved urea) was hold in the field 1 to 2 days to ensure that most of the $\mathrm{N}$ absorbed into the soil and to minimize losses of $\mathrm{N}$ through run-off water. To check the uniformity of fertilizer distribution over the field, three locations in each field were selected according to the following criteria: (a) near the irrigation water inlet, (b) center of the field and (c) near the water outlet. From the each experimental site, one raw (including 10 hills) were selected for data collection.

\section{Growth}

Leaf $\mathrm{N}$ content, SPAD value and plant height were measured from three locations in each field at full heading stage (70 DAT). Ten readings of chlorophyll meter (SPAD-502, Minolta, Japan) and plant height were taken from each experimental plot. Leaf $\mathrm{N}$ content was measured with Agri Expert CCN-6000 (Satake Co. Ltd., Japan). Leaf $\mathrm{N}$ content and SPAD values were measured at one point on the middle of the leaf blade of topmost fully expanded leaf.

\section{Yield}

At time of harvesting, grain yield was recorded from the sampling area $\left(3 \mathrm{~m}^{2}\right)$ of three locations of each experimental plot. Yield and yield components were measured as grain yield per hector at 15\% moisture content, number of spikelet per panicle and thousand grain weight. From randomly selected ten panicles of harvested area, number of spikelet per panicle and thousand grain weight were measured. The yield maps were created by using real-time yield monitoring system developed by Yanmar Co. Ltd for a head-feeding IT combine harvester (AG6100R) that included a yield monitoring system and weighted proportional distribution method. In this IT combine harvester, yield and moisture are monitored by a sensor which located at the input slot of the grain tank through probing the grains flow rate. This combine is equipped with global positioning hardware, and provides real-time measurement of yield ( 5 times per second) during harvesting for local-

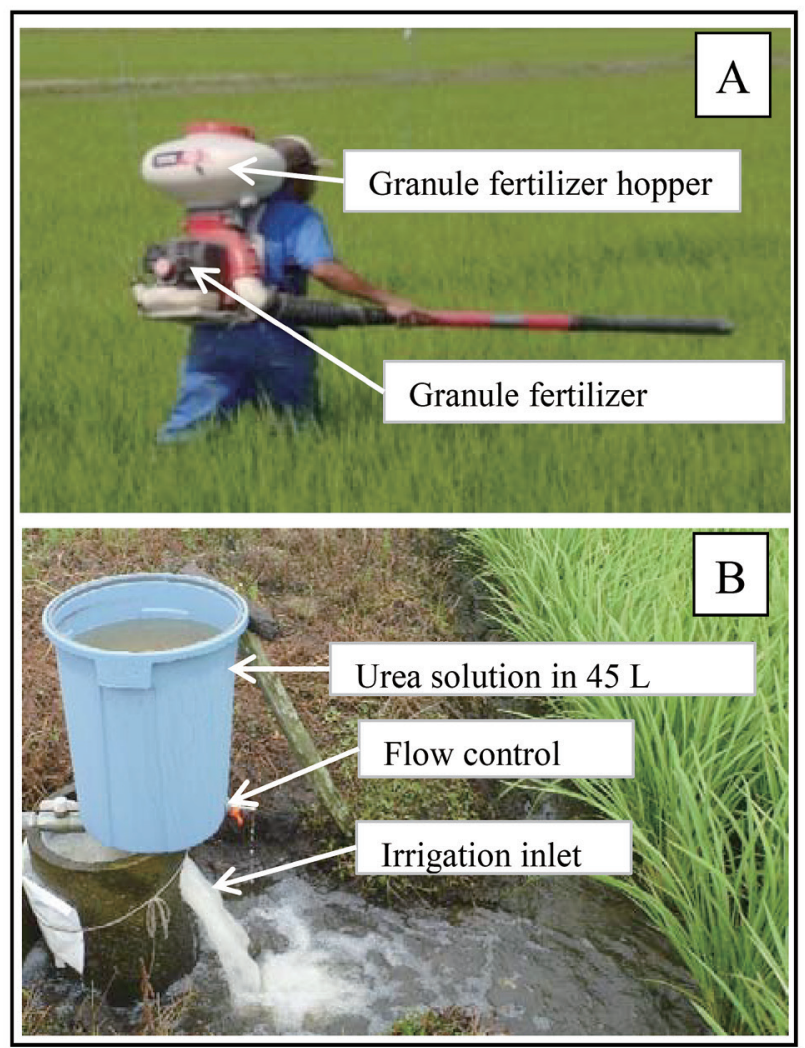

Fig. 1. Equipment used in two types of fertilizing methods. Granules of urea fertilizer spreading by granule spreader (A). Urea fertilizer dissolved with water in plastic container and distributed with irrigation water from the water inlet (B).

ized areas within the field. The list of the gain yield data $\left(\mathrm{kg} / \mathrm{m}^{2}\right)$ obtained from IT combine harvester in each $1 / 5$ second were converted to 120 points grain yield data $\left(\mathrm{kg} / 83.3 \mathrm{~m}^{2}\right)$ using the real-time harvesting speed $(\mathrm{m} /$ $\mathrm{sec}$ ) of the combine harvester, which then the coefficient of variation (CV\%) was calculated for expression of yield variation within a same experimental plot.

$$
C V \%=\frac{\delta}{\mu} \times 100 \%
$$

where $\delta$ and $\mu$ are standard deviation and arithmetic mean of the yield in experimental plot, respectively.

\section{Labor cost}

The labor costs for $\mathrm{N}$ topdressing under two different fertilizer application methods were calculated according to Ibaraki-Prefectural average hourly labor cost in 2015 (MHLW, 2016) and presented as absolute labor cost per hector (yen ha $\mathrm{h}^{-1}$ ), labor cost for 1 ton grain production (yen $\mathrm{t}^{-1}$ ) and relative values for labor cost (\%). The relative values for labor cost were calculated by using the value of each fertilization method multiplied by 100 and then divided by the corresponding value for GA method.

\section{Statistical analysis}

All data were subjected to factorial analysis of variance (ANOVA) considering "Urea application method" and "Location of the field" as main factors and using 


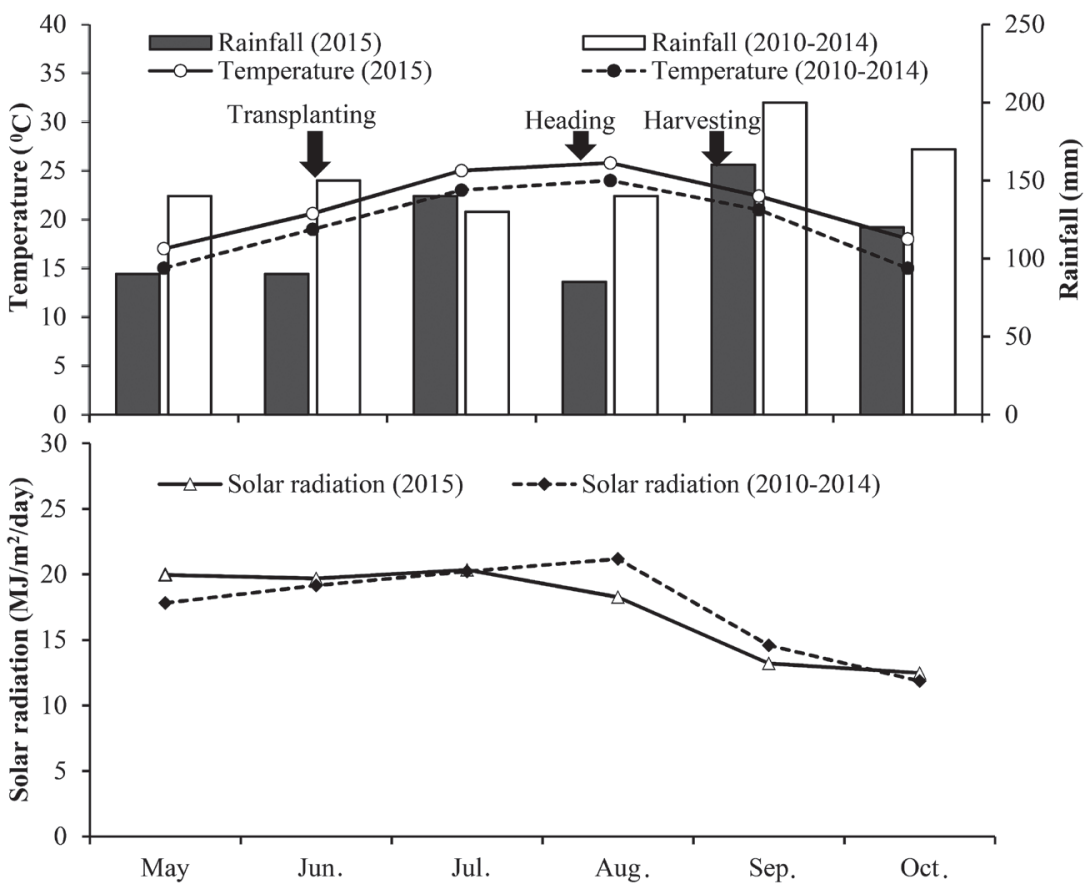

Fig. 2. Variation of monthly average air temperature, rainfall and solar radiation during the rice growing period in 2015 .

3 fields as replicates. All statistical analysis was performed with the software statistics analysis system (Institute SAS, 2002).

\section{RESULTS}

\section{Temperature, rainfall and solar radiation}

Temperature dynamics, rainfall distribution and solar radiation pattern during the rice growing season in 2015 and last 5 years showed in Fig. 2. The average daily temperature was $21.9^{\circ} \mathrm{C}$ and total precipitation were $930 \mathrm{~mm}$ during the rice growing season in 2015 . However, according to past years field weather data, average daily temperature during the rice growing season in 2015 was higher than its average value of last 5years. Moreover, monthly total precipitation was lower than its average value of last 5 years. The average daily solar radiation during the rice growing season in 2015 was $17.3 \mathrm{MJ} \mathrm{m}^{-2}$ day $^{-1}$ and it was all most similar with the average solar radiation value of 2010 -2014 (last 5 years).

\section{Growth}

Based on pooled data of leaf $\mathrm{N}$ content at full heading stage, significantly higher values were observed near the water inlet and center of the field in urea applied by PA method than GA method (Fig. 3a). Leaf $\mathrm{N}$ content ranged from $3.7 \%$ to $3.8 \%$ in urea applied by PA method and from $3.4 \%$ to $3.7 \%$ in urea applied by GA method (Fig. 3a). The significant difference in leaf $\mathrm{N}$ content was not found among locations of the field of PA method. When urea fertilizer applied by GA method, leaf $\mathrm{N}$ content was significantly higher near the outlet than inlet and center of the field (Fig. 3a).

The SPAD value at full heading stage ranged from
39.5 to 41.5 in urea applied by PA method and from 38.6 to 40.4 in urea applied by GA method (Fig. 3b). The significant difference in SPAD value was not found among locations of the field of PA method. When urea applied by GA method, SPAD value was significantly higher near the outlet than inlet and center of the field (Fig. 3b). There were significantly higher SPAD values near the water inlet and center of the field in urea applied by PA method than those values in GA method. On the other hand, the pattern of leaf $\mathrm{N}$ content were similar with pattern of SPAD values.

The topdressing urea application method did not influence the plant height at full heading stage significantly. However, numerically the taller plants were found from PA method near the inlet and center of the field (Fig. 3c). The significant differences in plant height were not found among locations of the field of PA method. However, significantly higher average plant height values were observed near the water outlet in urea applied by GA method than those values in water inlet and center of the field.

\section{Yield related parameters}

The method of topdressing urea application was significantly influences the variation in grain yield $(\mathrm{t}$ $\mathrm{ha}^{-1}$ ) within the same experiment field (Table 1). The highest grain yield $\left(5.2 \mathrm{t} \mathrm{ha}^{-1}\right)$ was obtained from PA method whereas GA method produces $4.8 \mathrm{t} \mathrm{ha}^{-1}$. The average grain yield difference between PA method and GA method was significant at $10 \%$ level. However, the data presented in Table 1 revealed that the average number of spikelet per panicle and 1000-grain weight of PA method were numerically higher than GA method but not significantly different at 10\% level. Fig. 4 demonstrates the relationship between leaf $\mathrm{N}$ content at 

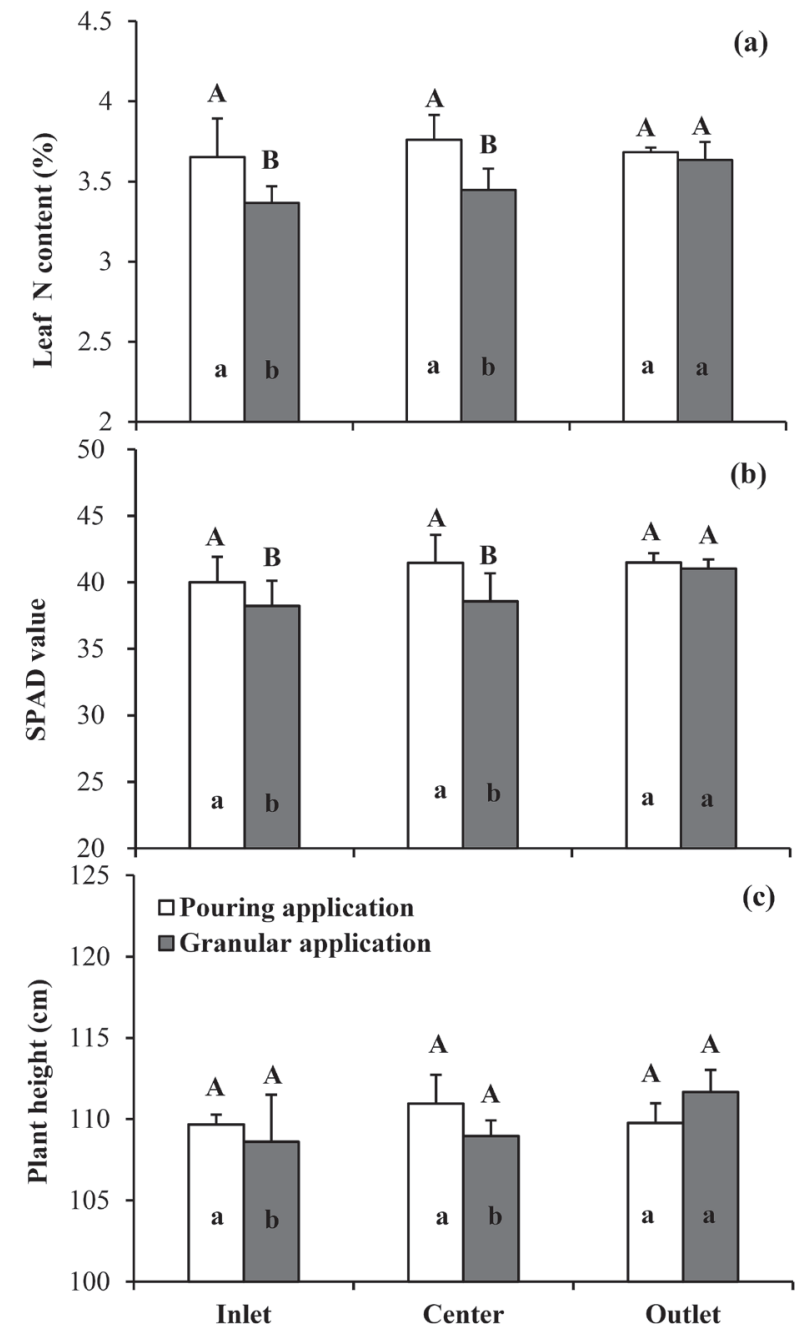

Fig. 3. Leaf $\mathrm{N}$ content (a), SPAD value (b) and plant height (c) of rice in three locations in the field at full-heading stage as affected by urea application method. Capital letters (A, B) are indicated above the error bars show no significant difference $(\mathrm{P}<0.1)$ between application methods within each location; bars labeled with the same lowercase letters ( $\mathrm{a}, \mathrm{b})$ show no significant difference $(\mathrm{P}<0.1)$ between locations for each application method.

full-heading stage and grain yield of rice, where two separate clusters of leaf $\mathrm{N}$ content and grain yield are present; lower leaf $\mathrm{N}$ content relates to lower grain yield and higher leaf $\mathrm{N}$ content relates to higher grain yield. According to Fig. 4, lower values of leaf $\mathrm{N}$ content and grain yield are representing GA method and higher values of leaf $\mathrm{N}$ content and grain yield are representing

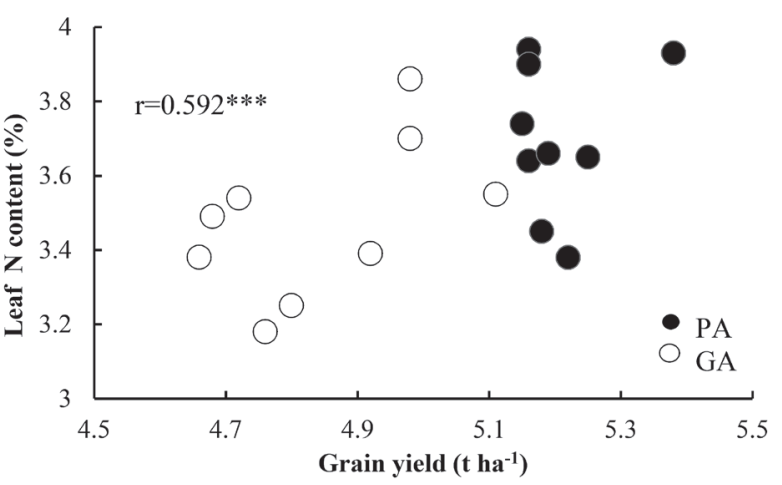

Fig. 4. Correlation between leaf $N$ content at full-heading stage and grain yield of rice. $* * *=$ Significant at $\mathrm{P}<0.001$

PA method.

ANOVA of the grain yield showed significant differences between urea application methods and location of the field at $10 \%$ level (Table 2). The yield variation within the same field was significant for GA method and not significant for PA method. The statistical analysis of the number of spikelet per panicle data was indicated urea application method and location of the field were not significant at 10\% level. Meanwhile, ANOVA of the 1000-grain weight data indicated only field location in GA method significantly effect, whereas urea application method and field location in PA method were not significant (Table 2).

The yield maps were created by using real-time harvesting data of the selected rice field in this experiment. The tendency of proportional variation in yield between PA method and GA method was different. Comparing the coefficient of variation (CV) indicates that among the yield map data, the higher variation of grain yield occurs in GA method (Fig. 5d, 5e and 5f), while lower variation of grain yield occurs in PA method (Fig. 5a, 5b and 5c). This yield variation was even more pronounced with $\mathrm{F}$ statistical values of grain yield and thousand grain weight in Table 2. However, yield maps were not clearly reviled that the proportional yield differences among inlet, center and outlet of the field.

\section{Contribution of urea application method to labor cost and productivity}

Economic assessment for rice production under two urea application methods was also made by using

Table 1. Effect of urea application method on grain yield and yield components of rice

\begin{tabular}{cccc}
\hline Methods of application & Grain yield $\left(\mathrm{t} \mathrm{ha}^{-1}\right)$ & Number of spikelets per panicle & 1000-grain weight $(\mathrm{g})$ \\
\hline PA & 5.2 & 99.1 & 25.5 \\
GA & 4.8 & 98.1 & 24.8 \\
\hline t-test & $\dagger$ & NS & NS \\
\hline
\end{tabular}

PA = Pouring application, $\mathrm{GA}=$ Granular application

Data were expresed as the means of nine samples.

$\dagger=$ Significant at $\mathrm{P}<0.1, \mathrm{NS}=$ Not significant 
Table 2. The effects of urea fertilizer application method and field location on grain yield and yield components of rice

\begin{tabular}{lcccc}
\hline \multirow{2}{*}{ Factors } & & 1000-grain weight & Grain yield & Number of spikelet per panicle \\
\cline { 2 - 5 } & DF & F & F & F \\
\hline Application method & 1 & $1.1^{\text {NS }}$ & $12.6^{\dagger}$ & $3.4^{\text {NS }}$ \\
Field location in PA & 2 & $3.3^{\text {NS }}$ & $1.2^{\text {NS }}$ & $0.1^{\text {NS }}$ \\
Field location in GA & 2 & $4.8^{\dagger}$ & $5.2^{\dagger}$ & $0.1^{\text {NS }}$ \\
\hline
\end{tabular}

$\mathrm{DF}=$ Degree of freedom, $\mathrm{F}=\mathrm{F}$ statistical value

$\dagger=$ Significant at $\mathrm{P}<0.1, \mathrm{NS}=$ Not significant

the simulated data from rice growing season in 2015. Labor cost calculated with Ibaraki-Prefectural average hourly labor cost in 2015 (MHLW, 2016). The results indicated that PA method reduced labor cost of about $80 \%$ for $\mathrm{N}$ fertilizer application. Further statistical analysis of the labor cost for $\mathrm{N}$ fertilizer application indicated PA method was resulted significantly $(\mathrm{P}<$ 0.1) lower cost than GA method (Table 3). As well as PA method was contributed to average simulated grain yield increase of $7.3 \%$ than GA method and, the effect of urea application method on average simulated grain yield deference was significant at 10\% level (Table 3).

\section{DISCUSSION}

\section{Influence of urea application method on plant growth parameters}

Nitrogen plays a key role in rice production and it is required in large amount. Nitrogen is one of the most important nutrients essential for the growth of crop,

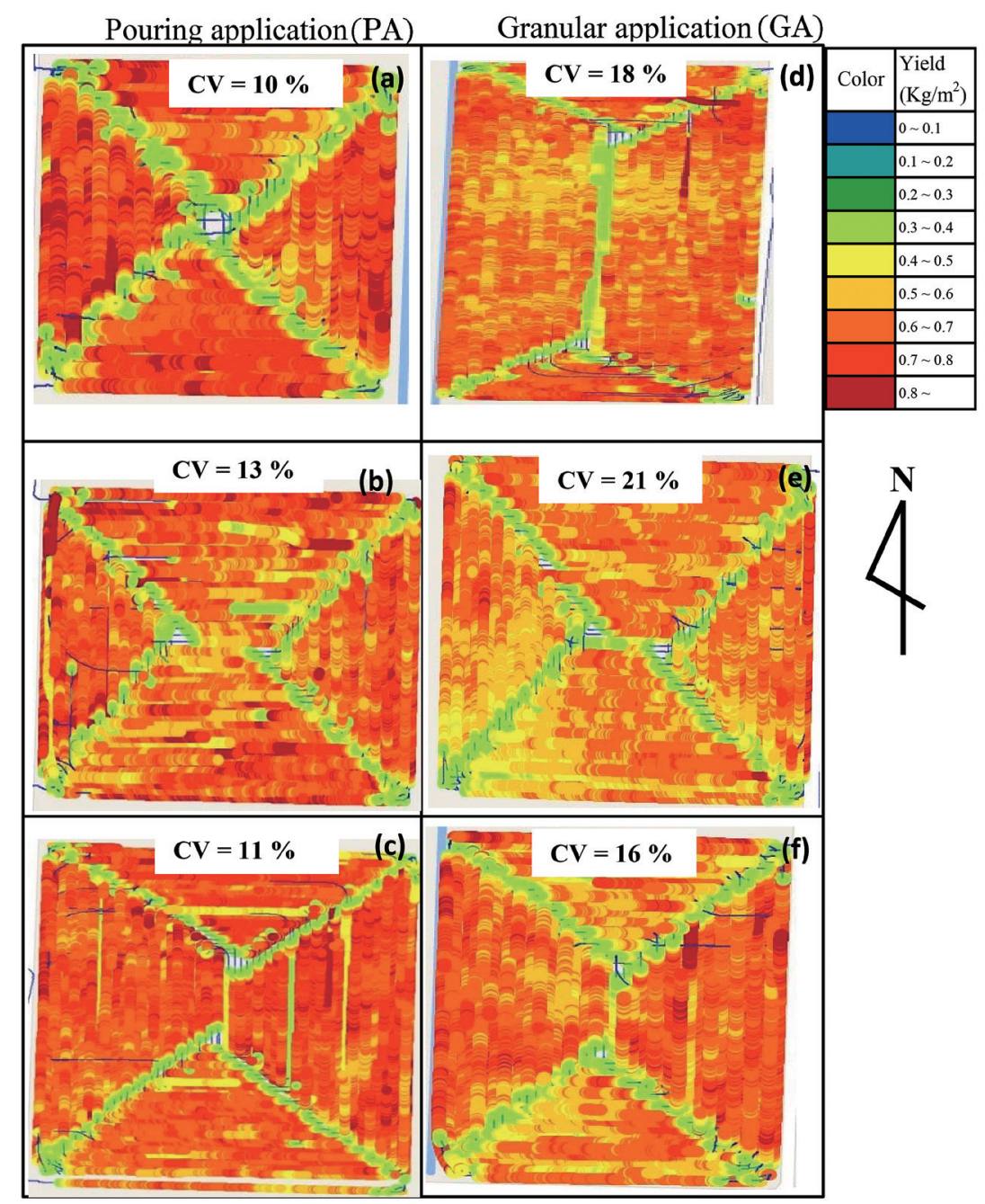

Fig. 5. Yield map created by real-time harvesting data under fertilizer application in PA method (a, b and c) and GA method (d, e and f).

$\mathrm{CV}=$ Coefficient of variation, $\mathrm{n}=120$ 
Table 3. Contribution of urea fertilizer application method on labor cost and simulated grain yield for 2015

\begin{tabular}{|c|c|c|c|}
\hline Items & PA & GA & t-test \\
\hline Labor cost for urea fertilization (yen $\mathrm{ha}^{-1}$ ) & 832.5 & 3875.0 & $\dagger$ \\
\hline Relative labor cost for urea fertilization (\%) & 21.5 & 100.0 & - \\
\hline Average simulated grain yield $\left(\mathrm{kg} \mathrm{ha}^{-1}\right)$ & 5206.6 & 4853.3 & $\dagger$ \\
\hline Relative grain yield (\%) & 107.3 & 100.0 & - \\
\hline Urea fertilization labor cost for 1 ton grain production $\left(\right.$ yen $t^{-1}$ ) & 159.9 & 798.4 & $\dagger$ \\
\hline Relative urea fertilization labor cost for 1 ton grain production (\%) & 20.0 & 100.0 & - \\
\hline
\end{tabular}

* Labor cost calculated with Ibaraki-Prefectural average hourly labor cost in 2015 (MHLW, 2016).

$\dagger=$ Significant at $\mathrm{P}<0.1, \mathrm{NS}=$ Not significant

and is a major component of chlorophyll and protein which are closely associated with leaf color, crop growth and yield (Fageria et al., 2011). Growth of rice plant was greatly influenced by different methods of application of urea fertilizer. Specific N management has the potential to increase fertilizer use efficiency as well as grain yield in the farmers' fields (Nath et al., 2013). Precise application of $\mathrm{N}$ fertilizer based on plant need in the field greatly improves fertilizer use efficiency in rice.

The average leaf $\mathrm{N}$ content and SPAD value at full heading stage in PA method was significantly higher than GA method. These results are indicating that $\mathrm{N}$ topdressing application method were greatly influence the chlorophyll content of the plant at full heading stage. However, the leaf $\mathrm{N}$ contents in both fertilizer application methods remaining higher than the minimum level of required $\mathrm{N}$ for the crop, which is $3 \%$ (Ambrosano et al., 1996). Similar results were obtained by Ichikawa et al. (1995), who observed that the $\mathrm{N}$ fertilizer application with pump-out from water inlet resulted higher leaf $\mathrm{N}$ content and SPAD value compared with control, linking this results to the $\mathrm{N}$ use efficiency of rice plant. In this study $\mathrm{N}$ topdressing by GA method was influence to numerically lower average plant height when compared with PA method at full heading stage. These variations in plant height might be due to the uneven and unbalance application of $\mathrm{N}$ fertilizer by GA method. These findings supported the results reported by BRRI (2010). They found that the application of $\mathrm{N}$ increased the plant height significantly.

Further less variation of leaf N content, SPAD value and plant height were observed in PA method than GA method suggesting that PA method greatly effect for the evenly distribution of $\mathrm{N}$ fertilizer throughout the field, less $\mathrm{N}$ losses and higher vegetative growth of rice plant. As well as plant height difference among locations of the field were significant with GA methods. The average shorter plant height in the inlet and center of the field under GA method might be the effect of excess amount of urea in the soil due to higher dose and uneven application causes failures of equal $\mathrm{N}$ uptake by the plant for proper growth.

\section{Influence of urea application method on compo- nents of grain yield and yield variation}

The results of this study conducted in real field condition, i.e., on commercial large-scale farm and with two different $\mathrm{N}$ topdressing application methods, showing an advantage in PA method for increase grain yield (Table 1). Uddin et al., (2013) found that $\mathrm{N}$ fertilizer has significant role in yield increment of rice. Highest grain yield in PA method might be due to significantly higher leaf $\mathrm{N}$ content $(\mathrm{P}<0.05)$ and higher SPAD value $(\mathrm{P}<0.1)$. As shown in Fig. 4 , leaf $\mathrm{N}$ content is positively correlated with grain yield. According to Matsushima (1966), significantly higher leaf N content has greatly effect on rice yield. This assuming that the amount of $\mathrm{N}$ in the forms of absorbable by rice plants in fertilizer application by PA method might be higher than GA method. Because, urea breakdown begins as soon as it is apply to the soil. When urea applied with GA method, if the soil is dry, no reaction happens. But with the enzyme urease, plus any small amount of soil moisture, urea normally by hydrolyzes and converts to ammonium and carbon dioxide. This can occur in 2 to 4 days and happens quicker on high $\mathrm{pH}$ soils. Unless ammonium incorporated with water in the field, ammonia might be loss. The volatility of urea depends on various factors in the field such as soil temperature and soil pH (Curtis et al., 2016). However, urea losses to air by gaseous ammonia greatly reduced by application as liquid urea in PA method.

Eskandari et al., (2011) reported that positive correlation (0.62) for filled grain number per panicle with yield. In this study the average number of spikelet per panicle was numerically higher but not significant at $10 \%$ level in PA method. Number spikelet per panicle is one of the most important traits in rice productivity determination. The number of spikelet is established in the early stages of panicle development. Nitrogen fertilizer application efficiently before panicle initiation stage is well known to increase spikelet number. The effects of $\mathrm{N}$ fertilizer on panicle branching may be mediated by cytokinin, in which accumulation in the inflorescence meristem can regulate panicle development, resulting in increased numbers of spikelet and branches (Ding et al., 2014).

Widespread acceptance of urea was delayed in part due to its greater potential for $\mathrm{N}$ loss via ammonia vola- 
tilization (conversion from dissolved ammonia to ammonia gas). And, urea application with irrigation water with proper management practices losses can be negligible (Clain et al., 2007). In this study, lower grain yield in GA method were recorded and this would be related to the greater potential for $\mathrm{N}$ loss via ammonia volatilization in urea by GA method. While, the PA method would be contribute to the lower $\mathrm{N}$ losses.

According to the Table 2, the effect of urea application method and field location in GA method was significant $(\mathrm{P}<0.1)$ on grain yield. Fig. 5 shows the realtime yield map created by yield monitoring system in head-feeding combine harvester. The coefficient variation were calculated by the data were collected from the software installed in combined harvester, revealed that the proportional yield variation within the field was lower in PA method than GA method. Further, variation in grain yield and 1000-grain weight among three locations within the field was significant $(\mathrm{P}<$ 0.1 ) in GA method, indicating that PA method would be related to greater potential for uniform $\mathrm{N}$ application than GA method. Significant yield variation within the field might be result of the significant variation in leaf $\mathrm{N}$ content, SPAD value and plant height at full heading stage in GA method (Fig. 3). This suggests that grain yield and other yield related parameters highly dependent on efficient $\mathrm{N}$ fertilizer application at panicle initiation stage. However, Hung et al., (2008) indicated that uniform $\mathrm{N}$ application for rice without consideration of crop growth and $\mathrm{N}$ nutrition status in a field may result in over-fertilizer application in some locations but nutrient deficiency in others. Excessive $\mathrm{N}$ fertilizer has been reported as a cause of environment pollution (Booltink et al., 2001; Verhagen, 1997) while N deficiency restricted crop growth and yield (Kim, 2004; Miyama, 1998). Even though, the PA method was exhibited significantly higher gain yield than GA method from the data of this experimental site in 2015 cultivation season, the average yield differences in last 5 years was not significant between PA and GA method.

\section{Labor cost of PA method vs. GA method}

The economic impact of PA method compared to GA method is determined by changes in cost of production and rice yield. In this study, the average simulated grain yield and relative grain yield in PA method were higher than GA method. As discussed before, PA method was chosen for optimize their labor efficiency and improve the yield of larger rice fields in large-scale paddy farming, thus differed from GA method, resulting less labor cost for fertilizer application. In addition to the labor cost reduction, cost of the apparatus and there maintenance cost for PA method was greatly reduced than GA method. In Yokotanojo Co. Ltd., implied labor for topdressing urea application by PA method greatly reduced working hours (33.3 $\mathrm{min} \mathrm{ha}^{-1}$ ) compared to the GA method (155 min ha ${ }^{-1}$ ), thus PA method contributed to significantly reduced labor cost of about $80 \%$ than GA method. According to the their several years' experience on PA method, time consump- tion and efficiency of $\mathrm{N}$ fertilizer application by PA method was greatly affected by the field area, in which only the field with more than 0.5 ha area could resulted higher efficiency than GA method.

\section{CONCLUTIONS}

In this study, conducted under real farm conditions, shows that application of $\mathrm{N}$ fertilizer using $\mathrm{PA}$ method in large-scale rice fields (1) reduced $\mathrm{N}$ losses and provide sufficient $\mathrm{N}$ with less yield variation, (2) obtained higher grain yield or no difference, and (3) greatly reduced labor cost for fertilizer application in compared to GA method.

Lower number of spikelet per panicle in GA method would be related to the greater potential for $\mathrm{N}$ loss via ammonia volatilization in GA of urea as $\mathrm{N}$ topdressing. The yield variation within the field might be result of the significant variation in leaf $\mathrm{N}$ content, SPAD value and plant height at full heading stage, suggest that grain yield highly dependent on efficient $\mathrm{N}$ fertilizer application at panicle initiation stage. This outcome was mostly related to evenly distribution and efficiently utilization of urea fertilizer in PA method. It was highlighted that PA method was cost effective, time efficient and evenly distributed fertilizer application method compared with GA method in large-scale rice farming. The Ibaraki Prefectural Agricultural Research Institute is currently conducting research to further improvements of efficiency of PA method.

\section{AUTHOR CONTRIBUTIONS}

U.A.P. PATHIRANA designed the study, performed the histological experiments, analyzed the data and wrote the paper, Y. MATSUE, T. NANSEKI and Y. CHOMEI analyzed the data and wrote the paper, S. YOKOTA designed the study, supervised the work, provided facilities and resource and wrote the paper. All authors assisted in editing of the manuscript and approved the final version.

\section{ACKNOWLEDGEMENTS}

This research (NoshoNavi 1000) is supported by grants from the project of the NARO Bio-oriented technology research advancement institution. We would like to thanks the Agriculture Research Institute of Ibaraki Prefecture, Japan for their help on data analysis. We are also grateful to Yanmar Co. Ltd for providing yield map creating facility for this experiment.

\section{REFERENCES}

Ambrosano, E. J., E. B. Wutke, E. A., Bulisani and H., Cantarella 1996 Feijão. In "Recomendações de adubação e calagem para o Estado de São Paulo", ed. by Raij B et al., Campinas, IAC, pp. 194-195

Booltink, H. W. G., G. J. Alphen, W. D. Batchelor, J. O. Paz, J. J. Stoorvogel and R. Vargas 2001 Tool for optimizing management of spatially variable field. Agri. Sys., 70: 445-476 
BRRI. 2010. Annual report of soil and fertilizer management programme. Bangladesh Rice Research Institute (BRRI), Joydebpur, Gazipur.

Clain, A. J., T. K. Richard, W. E. Jason, D. B. Brad and D. J. Grant 2007 Management of Urea Fertilizer to minimize Volatilization. Retrieved from http://www.extension.uidaho.edu/swidaho/nutrient\%20management/pnwureamanagement.pdf

Curtis, j. O., W. R. George and L. M. Harvey Fertilizer 2016 Fertilizer Urea. https://www.extension.umn.edu/agriculture/nutrientmanagement/nitrogen/fertilizer-urea/

Ding, C., J. You, L. Chen, S. Wang and Y. Ding 2014 Nitrogen fertilizer increases spikelet number per panicle by enhancing cytokinin synthesis in rice. Plant Cell Repots, 33(2): 363-371

Eskandari, C. F., H. Bahrami and A. Asakereh 2011 Evaluation of traditional, mechanical and chemical weed control methods in rice field. Aust. J. Crop Sci., 5(8): 1007-1013

Fageria, N.K., V.C. Baligar and C.A. Jones 2011 Growth and Mineral Nutrition of Field Crops, CRC Press, Boca Raton (USA)pp. 3

Hung, T., Nguyen, L. Kyu-Jong and L. Byun-Woo 2008 Recommendation of Nitrogen Topdressing Rates at Panicle Initiation Stage of Rice Using Canopy Reflectance. J. Crop Sci. Biotechnol., 11(2): 141-150

Ichikawa, T., M. Arisaka, S. Taneda and K. Ueki 1995 Fertilizer Application Method Pump out from Water Inlets for Ear Growth. Hokuriku Crop Sci., 30: 38-39

Institute SAS.SAS User's Guide 2002 SAS Institute Inc; Cary, NC, USA

Kim, M. H. 2004 Panicle nitrogen topdressing prescription based on nondestructive diagnosis of growth and nitrogen nutrition status at panicle initiation stage of rice. PhD thesis.Seoul Nation- al University, Seoul, Korea

Matsushima, S. 1966 Theory and Practice for Rice Cultvation. Yokendo Co. Ltd., Tokyo. 1-365

Miyama, M. 1998 A new method for standardization of fertilizer application for rice plant based on optimum nitrogen content. Spec. bull. Chiba-Ken Agri. Exp. Sta., 15: 1-92

MHLW, Regional minimum wages of Japan at a glance. Retrieved February 1, 2016, from http://www.mhlw.go.jp/stf/seisakunitsuite/bunya/kokyou_roudou/roudoukijyun/minimumichiran/

Nanseki, T., Y. Chomei, Y. Matsue 2016 Rice Farm Management Innovation and Smart Agriculture in TPP Era: Farming Technology Package and ICT Applications, Yokendo, Tokyo, Japan (in Japanese)

Nath, D. K., F. Haque, F. Amin and M. S. H. Islam 2013 Farmers' participatory site specific nutrient management in gangetic tidal floodplain soil for high yielding Boro rice (Oryza sativa L.). The Agriculturists, 11(1): 8-14

Saito, Y., M. Arisaka, T. Ichikawa and T. Sato 1997 Fertilizer Application at Panicle Formation Stage by Pumping out from Water Inlets. Hokuriku Crop Sci., 32: 22-24

Supaporn, P., T. Kobayashi and P. Pongsagorn 2012 Aspects of the aging farming population and food security in agriculture for Thailand and Japan. Int. J. Env. Ru. Dev., 3(1): 102-107

Uddin, S., M. A. R. Sarkar and M. M. Rahman 2013 Effect of nitrogen and potassium on yield of dry direct seeded rice $\mathrm{cv}$. NERICA 1 in aus season. Intl. J. Agron. Plant. Prod., 4(1): 69-75

Verhagen, J. 1997 Site-specific fertilizer application for potato production and effects on $\mathrm{N}$ leaching using dynamic simulation modeling. Agric. Ecosyst. Env. 66: 165-175 